\title{
ARCHETYPAL DOMINANT IN THE UKRAINIAN SECTOR OF SOCIAL NETWORKS
}

\author{
Khraban Tatyana \\ Candidate of Philology \\ ORCID ID 0000-0001-5169-5170 \\ Military Institute of Telecommunications and Information Technologies \\ Moskovska Str., 45/1, Kyiv, 01011, Ukraine \\ Xraban.Tatyana@gmail.com
}

The aim of the article is to analyze which archetypes are dominant in the personality, activities, objectives, self-concept of users of the Ukrainian sector of social networks and project as a manifestation of users' personal preferences and resonance in the posts on the social network Facebook. Materials and methods. Insight into phenomenon of identity has been carried out in the media-centered approach to understanding the personality. The essence of this approach based on psychoanalytic theory and extends to modern ideas about oneself and the people which a person encounters throughout his life. In this study the method of contextual and intuitive-logical interpretive analysis was used in order to identify the meanings of publications (aphorisms and quotations) based on personal experience and logical thinking. Content analysis was used to separate certain patterns into thematic groups, which made it possible to identify the dominant archetypes in publications. The posts (aphorisms and quotes) posted on the users' pages in the Ukrainian sector of social networks (780 units) provided inputs for the study. Results and discussions. Since archetypes are characteristic characters and plot elements, often represent key roles in life-story narratives with familiar and consistent traits, archetypal figures have become prototypes for a universal role model. Quotes and aphorisms are very common incentives for discussion on social networks. Personal preferences in this area are enough indicative to provide a complete picture of the issues of concern. Conclusions. The most common archetypes in the Ukrainian sector of social networks are "Sage", "Ruler", "Innocent", "Everyman", "Wizard". The share of these five archetypes is 73\%. The fact that the share of the three archetypes "Sage", "Innocent", "Explorer" reaches $42 \%$, indicates the prevalence of the strategy of individualism in social networks. The main characteristics of people using these three archetypes to build their identity are spiritual search, reflections on the world and their place in it, endless doubts about themselves, about the correctness/incorrectness of their choices, the desire to be a bright individual and to choose their own path. The full development of the personality and the realization individual's intentions as an end in themselves become a prerogative. Taking into account these circumstances, as well as the fact that social networks users are united in communities of interest, we can conclude there is a tendency in the development of constructive individualism in social networks - individuals consciously unite into groups to achieve their own goals and organize their lives.

Key words: archetype, identity, social networks, media-centered approach.

\section{Introduction}

The central position in the understanding of personality is identity that according to the psychosocial concept of personality development is interpreted not so much as internal integrity but as a result of agreement, balance between potential integrity, personal biases, values of society represented inter alia through the recognition of significant Others (Schwartz, 2001). Throughout life each person must develop his/her identity (or multiple identities) in order to fulfill certain social roles, form beliefs and life goals, develop self-esteem (Faber, 2009). The identification process arises when person seeks to be like an

(C) Khraban T., 2020 
individual (real or imaginary) whom he perceives as a man of note and subsequently tries to assimilate this person's values, beliefs and behavior (Block \& Turula, 1963). In this context, social networks have become effective and practical tool that helps person to form self-concept by his/her inclinations. In social networks, on the one hand, identification becomes a reinforcing factor for a person's personality giving him/her a sense of self-worth, on the other hand, identification contributes to the fact that the quest for intersubjective interaction becomes a need in the virtual space. Some studies within the media-centered approach to identity show that people choose and create (sometimes unintentionally) social and physical conditions that intensify and reflect elements of their personality, self-esteem and values (Rentfrow \& Gosling, 2006). For example, quotes and aphorisms are very common incentives for discussion on social networks, and personal preferences in this area are indicative enough to get an idea of the person of interest. In quotes and aphorisms posted on the social networks users' pages memories of their personal experiences are reflected, values, views, ideas about oneself, motives and emotions are manifested. M. Faber \& J. Mayer in their study proved that incentives which social networks users resonate with are partly based on archetypal themes (Faber \& Mayer, 2009). In addition, since social networks users often refer to repetitive types of incentives, which are an example of a thematic archetype, it is possible to assert, that this archetype acts as the current theme of personal life, it is defined as dominant in personality, activities, goals, self-concept and projected in personal preferences (Faber, 2009: 118-119). As the modern world has offered us an opportunity to decide how we live our lives, rather than being destined for certain social roles, the importance of archetypes becomes more evident (Schlegel et al., 2011). Thus, the relevance of the article is determined by new opportunities for comprehending the phenomenon of identity in media-centered approach to understanding the personality, the essence of which bases upon psychoanalytic theory and extends to modern ideas of self and other people that a person encounters throughout his/her life (Faber, 2009).

\section{Analysis of recent researches and publications}

The most significant for this study is the theory of archetypes, which was originally proposed by C. Jung. C. Jung claimed that there is a set of cross-cutting themes and motives. He called them archetypes (or dispositions in the collective unconscious), which form images in consciousness (Jung, 1968). Whenever we see a real person, encounter any situation or event, face any problems we have powerful archaic images that emerge from the collective unconscious. These images elicit a strong emotional response that is incomprehensible for the person to understand (Shelburne, 1988). Modern theories of archetypes argue that the result of an emotional response occurring after meeting an archetypal image is an absolute awareness of the importance of this character, and archetypal models are transferred by cultural transmission, and not biologically, as originally C. Jung stated (McAdams, 2008; Guo \& Ma, 2018). An archetypal analysis regarding the individual preferences of archetypal characters and topics in social networks is impossible without reference to the neo-archetypal theory of "resonance" (Faber \& Mayer, 2009). Neo-archetypal theory emphasizes the human response to the archetype, which inspires a diffuse but strong emotional and affective reaction. This reaction is characterized mainly as a mixture of interests and sympathies called "resonance". Resonance can be characterized by describing a change in a person's mood during an experiment in which a hypothetical plot with the participation of archetypal figures is shown on the screen, or during an experiment in which the peculiarities of participants' response to a cultural pattern, for example, song or artwork are analyzed. M. Faber and J. Mayer note that the resonance to archetypes, just like a person's interpretation of the events that have occurred in his life, is not static, but dynamic: just like media preferences change and diversify, a person's resonance to any cultural incentive can change over time (Faber \& Mayer, 2009: 10). The works being relevant to this study are: V. Skleinis' paper (Skleinis, 2019) (models of the archetypal structures dynamics are considered as a variety of systems of meanings with different levels of presentation in the form of intrapersonal and interpersonal structures); D. Brent's paper (Brent et al., 2019) (a new technique, Archetype-Based Modeling and Search, that learns to identify new relevant documents based on a specified set of archetypes are 
developed); S. Shadraconis (Shadraconis, 2013) (the significance of archetypes through the modern idealization of leaders as heroes are explored) and other research works. In this study, based on empirical evidence, individual preferences for archetypal images in the Ukrainian sector of social networks has been identified for the first time. The scientific value of the research is the further development of the theory of archetypes in terms of determining the place, role and significance of the emerging phenomenon of the archetype in social networks, which makes it possible to comprehend the deep psychological processes of modern man.

The aim of this paper is to analyze which archetypes are dominant in the personality, activities, objectives, self-concept of the users in the Ukrainian sector of social networks, and are a demonstration users' personal preferences and resonance in the posts of the social network Facebook.

\section{Materials \& methods}

In order to achieve the objective general scientific research methods were used in the study: analysis, classification, observation, description. Furthermore, basing on the assertion "the analysis of discourse often deals with a set of cases - forms of certain phenomenon manifestation, which study is designed to reveal some regularity" (Kasavin, 2007: 110), we believe it would seem justifiable to use discourse analysis to identify the most popular archetypal images and motives in Ukrainian sector of social networks. At the same time, discourse analysis in the framework of psychological study on the text organization in specific socio-cognitive practices highlights the reflexive mechanisms settled in these practices and defined by them and, in turn, have a reciprocal effect on the practices (Kasavin, 2007: 111; Machikova, 2015). Therefore, in this study the method of contextual and intuitive-logical interpretive analysis was used in order to identify the meanings of publications (aphorisms and quotations) based on personal experience and logical thinking. Content analysis was used to separate certain patterns into thematic groups, which made it possible to identify the dominant archetypes in publications. The posts (aphorisms and quotes) posted on the users' pages in the Ukrainian sector of social networks (780 units) provided inputs for the study.

Results and discussions. Identification occurs when a person strives to be like someone whom he/her perceives as a model, and changes his personality in accordance with the standard and criteria of attractiveness of this model (Kalenich, 2020). People most often identify themselves with others who are admired. Observing the personal characteristics or behavior patterns of someone else, people (consciously or unconsciously) believe that possession of identical qualities can make them better and stronger, and then they integrate these characteristics into their lives. Identification process involves not a simple imitation but a long and purposeful internalization during which people tend to create a model that assumes that they correspond to a "type" - in fact, to a prototype of characteristics, behavior and character traits. People regularly observe, internalize and, if necessary, update these prototypes (Faber \& Mayer, 2009: 115). Since archetypes are characteristic plot characters and also often represent key roles in narratives with life scenarios that have familiar and consistent traits (Hillman, 1997) it is not surprising that it is the archetypal figures that become the prototypes of the universal role model. Neo-archetypal theory emphasizes the relational model of the self in the world organized around these characters. That is, many personal stories and life stories of people include familiar, archetypal figures enshrined in well-known roles. This research uses the Archetypes System developed by C. Pearson (Pearson, 2012) as a personality typology and a theoretical construct for determining which archetypes are dominant in personality, activity, objectives, self-concept of users of the Ukrainian sector of social networks. The analysis of publications proved the most common archetype in the Ukrainian sector of social networks is "Sage" (23\% of the total sample). Based on this archetype, users position themselves as a mentor, expert, philosopher, adviser, contemplator (Три речі ніколи не повертаються назад - час, слово; можливість. Тому: не втрачай часу, вибирай слова, не пропускай нагоду; Не варто боятися щзастя. Воно швидко минає; Залиш каламутну воду в спокої, $і$ вона стане чистою і прозорою). The main characteristics of this type of 
people are the narcissistic belief that they have the right to advise because they have some kind of secret knowledge, they see someone else's situation objectively, quest for supremacy, need for a sense of self-worth, self-reflection (Немає формули успіху, але є формула невдачі: спробуйте всім сподобатися; Не варто приймати доброту за слабкість, грубість за силу, а підлість за вміння жити).

Users of the Ukrainian sector of social networks also often refer to the archetype "Ruler" (19\%) positioning themselves as an organizer ( Усnix - ųе радість, і свобода, і дружба) and administrator. The main features of this type of people are a quest for dominance, self-worship, the pursuit of recognition, the need to demonstrate success and strength, excessive purposefulness and desire constantly and in everything to be number one (Успішна людина має програму дій, невдаха має поважну причину; Сила характеру не в умінні пробивати стіни, а в умінні знаходити двері; Немає проблем, є неприємні рішення).

Using the archetype "Innocent" (12\%) users present themselves as romantic, dreamer, kind-hearted man. The main features of this type of people are psychological comfort, which is reflected in a sense of well-being, joyful, stable mood and inexhaustible optimism, faith in humanity, belief that life is not accidental, and at the end of the life's path "goodness" will certainly triumph over "badness", willingness to change, grow, love, escape narrow domestic walls, feel deep interest, passionately strive for something, to give (Кожен день має своє чудо; Кращчй засіб добре почати день полягає в тому, щзб, прокинувщись, подумати, чи не можна хоч одній людині доставити сьогодні радість; Щоб побачити веселку, треба пережити дощ; Життя полягає не в тому, щьоб чекати, коли пройде буря, а в тому, шуоб навчитися таниювати під дощем)

Social media users use the archetype "Lover" (10\%) when they want to be seen as a friend, partner, loved one, lover. Referring to the archetype "Lover" users of social networks manifest a desire to receive emotional support, to exchange psychological signs of attention, sympathy and empathy. The specificity of the archetype "Lover" in the Ukrainian sector of social networks is the accentuation of such criteria as selflessness, devotion and loyalty, exactingness and integrity, sincerity and trust (Найбільша сила чоловіки-- любляча жінка. Вона - його честь, його віра, його гідність!; Підтримуйте інтимні стосунки. Будьте теплими, пристрасними $i$ тактильне приємними; Найкращий спосіб не розчаровуватися - нічого ні від кого не чекати; Кожній людині, якій ти даруєш довіру, ти даєш в руки ніж. Їм він може тебе захистити або знищити).

In the concept of the archetype "Wizard" (9\%) it is of utmost importance such roles as inspirer, prophet, comforter. The archetype "Wizard" correlates with certain qualities due to which the subject differs from ordinary people and is perceived as having supernatural, superhuman or exceptional abilities. The main features of this type of people are high selfconfidence, ability to motivate yourself and others, tendency to set clear goals for yourself and others, positive outlook on life (Слідуйте за своєю мрією, не дивлячись ні на щзо; Все буде так, як ти мрієш, тільки почекай. Пам'ятай, иукор на дні; Я вірю в тебе, у тебе все вийде!; Коли одна мрія збулася - іди за новою).

Using the "Explorer" archetype (7\%) social media users position themselves as an individualist, heart of flint, rioter. This type of people is characterized by the search for the true life purpose, sense of existence, quest for new spiritual guidelines, a new paradigm of life. The main features of this type of people are the focus on personal growth and spiritual selfimprovement (Не пливи за течією, не пливи проти течї - пливи туди, куди тобі треба)

Referring to the archetype "Rebel" (5\%) users of the Ukrainian sector of social networks position themselves as a maximalist, unmasker, person with radical tendency, oppositionist. The main features of this type of people are aggressiveness, imposing their ideals on others, extreme exactingness to other people, being too harsh, elevating their ideals to absolute rank, excessive ambition, rigidity, intransigence, inability to understand another person, unsociability, unwillingness to recognize the right of other people to be different, to have their own opinion, a sense of significance and importance, drive to achieve their objective by any means (Я живу в цььому світі не для того, щүоб відповідати вашим очікуванням; Мріі 
мають властивість проростати, ламаючи самі товсті стіни; Завжди вибирайте найважчий шлях - на ньому Ви не зустрінете конкурентів).

Under the guise of the archetype "Jester" (5\%) social media users often hide personal fears, worries and inner discomfort. In this case, humor acts as a psychological defense mechanism having the purpose of extinguishing painful emotional experiences, such as sadness, dissatisfaction. The main features of this type of people are vulnerability, inward discomfort (Я просто виглядаю як лось, а в душі я метелик).

In the perspective of the archetype "Caregiver" $(5 \%)$ the absence of complaints, the desire to look good in the eyes of others are in favor, such people do not know how to defend their interests, put up with inconveniences, do not dare to get out of exhausting relationships, suppress their feelings, do not know how to live for themselves, often make another person the center of their life, they try to seem sweetie, to be appreciated and loved. Social media users who post aphorisms and quotes in order to get the maximum number of "likes", gain approval and be loved, while the content of these posts does not correspond to their ideals, are secretive, distrustful, calculating, hypocritical, prone to manipulation (Цінуй кожну людину, навіть якщо він з'явився на мить. Адже, якщо він з'явився, то це вже не просто так!).

Referring to the archetype "Hero" (3\%) users of the Ukrainian sector of social networks position themselves as a warrior, charismatic leader, superman and demonstrate such character traits as purposefulness, centering on own ideas, abnormal hypertrophy of certain desires ( $P a_{3}$ вже почав - перемагай).

In the aspect of the archetype "Creator" (1\%) it should be noted stress resistance, creativity, innovation, adaptability. These traits are inherent for psychologically stable people who perceive failures as temporary obstacles, their optimistic thinking helps them to resist difficulties (Виберись на скелю, на яку ти мріяв піднятися, або навчися грати на трубi, відкрий нову справу, навчися любити музику, вивчи ще одну іноземну мову...).

Referring to the archetype "Parent" (1\%) users of the Ukrainian sector of social networks position themselves as an example of self-sacrifice for which a person enhances the importance of selfless love. This type of people is bearer of the culture of sacrifice and martyrdom, which are moral principles deeply rooted in the self-consciousness and closest to the ideal of Gospel sacrifice. This is a humble and courageous state of mind, the path of conscious "self-abasement" to save others (Іноді турбота про інших і є справжній дар).

Research findings are summarized in Table 1 "The linkage between the giving preference to archetypes by the person and his/her psychological characteristics".

Table 1

\begin{tabular}{|l|l|l|}
\hline $\begin{array}{l}\text { Archetypal } \\
\text { figures (in } \\
\text { descending } \\
\text { order of } \\
\text { share) }\end{array}$ & \multicolumn{1}{|c|}{ Key roles } & \multicolumn{1}{|c|}{ Psychological characteristics } \\
\hline Sage & $\begin{array}{l}\text { mentor, } \\
\text { expert, } \\
\text { philosopher, } \\
\text { adviser, } \\
\text { contemplator }\end{array}$ & $\begin{array}{l}\text { narcissistic belief that they have the right to advise because } \\
\text { they have some kind of secret knowledge, they see someone } \\
\text { else's situation objectively, quest for supremacy, need for a } \\
\text { sense of self-worth, self-reflection }\end{array}$ \\
\hline Ruler & $\begin{array}{l}\text { organizer, } \\
\text { administrator }\end{array}$ & $\begin{array}{l}\text { quest for dominance, self-worship, the pursuit of } \\
\text { recognition, the need to demonstrate success and strength, } \\
\text { excessive purposefulness and desire constantly and in } \\
\text { everything to be number one }\end{array}$ \\
\hline Innocent & $\begin{array}{l}\text { romantic, } \\
\text { dreamer, } \\
\text { kind-hearted } \\
\text { man }\end{array}$ & $\begin{array}{l}\text { psychological comfort, which is reflected in a sense of well- } \\
\text { being, joyful, stable mood and inexhaustible optimism, faith } \\
\text { in humanity, belief that life is not accidental, and at the end } \\
\text { of the life's path "goodness" will certainly triumph over } \\
\text { "badness", willingness to change, grow, love, escape }\end{array}$ \\
\hline
\end{tabular}




\begin{tabular}{|c|c|c|}
\hline & & $\begin{array}{l}\text { narrow domestic walls, feel deep interest, passionately } \\
\text { strive for something, to give }\end{array}$ \\
\hline Lover & $\begin{array}{l}\text { friend, } \\
\text { partner, } \\
\text { loved one, } \\
\text { lover }\end{array}$ & $\begin{array}{l}\text { quest for receiving emotional support, exchanging } \\
\text { psychological signs of attention, sympathy and empathy; } \\
\text { selflessness, devotion and loyalty, exactingness and } \\
\text { integrity, sincerity and trust }\end{array}$ \\
\hline Wizard & $\begin{array}{l}\text { inspirer, } \\
\text { prophet, } \\
\text { comforter }\end{array}$ & $\begin{array}{l}\text { high self-confidence, ability to motivate yourself and } \\
\text { others, tendency to set clear goals for yourself and others, } \\
\text { positive outlook on life }\end{array}$ \\
\hline Explorer & $\begin{array}{l}\text { individualist, } \\
\text { heart of flint, } \\
\text { rioter }\end{array}$ & $\begin{array}{l}\text { focusing on search for the true life purpose, sense of } \\
\text { existence, personal growth and spiritual self-improvement; } \\
\text { quest for new spiritual guidelines, a new paradigm of life }\end{array}$ \\
\hline Rebel & $\begin{array}{l}\text { maximalist, } \\
\text { unmasker, } \\
\text { person with } \\
\text { radical } \\
\text { tendency, } \\
\text { oppositionist }\end{array}$ & $\begin{array}{l}\text { aggressiveness, imposing ideals on others, being too harsh, } \\
\text { elevating their ideals to absolute rank, excessive ambition, } \\
\text { rigidity, intransigence, inability to understand another } \\
\text { person, unsociability, unwillingness to recognize the right } \\
\text { of other people to be different, to have their own opinion, a } \\
\text { sense of significance and importance, drive to achieve their } \\
\text { objective by any means }\end{array}$ \\
\hline Jester & jester & vulnerability, inward discomfort \\
\hline Caregiver & sweetie & $\begin{array}{l}\text { the desire to look good in the eyes of others; inability to } \\
\text { defend their interests, put up with inconveniences, get out } \\
\text { of exhausting relationships, to live for themselves; quest for } \\
\text { seeming sweetie, being appreciated and loved; secretive, } \\
\text { distrustful, calculating, hypocritical, prone to manipulation }\end{array}$ \\
\hline Hero & $\begin{array}{l}\text { warrior, } \\
\text { charismatic } \\
\text { leader, } \\
\text { superman }\end{array}$ & $\begin{array}{l}\text { purposefulness, centering on own ideas, abnormal } \\
\text { hypertrophy of certain desires }\end{array}$ \\
\hline Creator & $\begin{array}{l}\text { author, poet, } \\
\text { creator }\end{array}$ & $\begin{array}{l}\text { psychologically stability, optimistic thinking, stress } \\
\text { resistance, creativity, innovation, adaptability }\end{array}$ \\
\hline Parent & $\begin{array}{l}\text { example of } \\
\text { self-sacrifice }\end{array}$ & $\begin{array}{l}\text { quest for sacrifice and martyrdom; humble and courageous } \\
\text { state of mind; conscious "self-abasement" to save others }\end{array}$ \\
\hline
\end{tabular}

Conclusions. The most common archetypes in the Ukrainian sector of social networks are "Sage", "Ruler", "Innocent", "Everyman", "Wizard". The share of these five archetypes is $73 \%$. The fact that the share of the three archetypes "Sage", "Innocent", "Explorer" reaches $42 \%$, indicates the prevalence of the strategy of individualism in social networks. The main characteristics of people using these three archetypes to build their identity are spiritual search, reflections on the world and their place in it, endless doubts about themselves, about the correctness/incorrectness of their choices, the desire to be a bright individual and choose their own path. The full development of the personality and the realization individual's intentions as an end in themselves become a prerogative. Taking into account these circumstances, as well as the fact that social media users are united in communities of interest, we can conclude there is a tendency in the development of constructive individualism in social networks, that is, individuals consciously unite into groups to achieve their own goals and organize their lives.

\section{REFERENCES}

Kalenich, 2020 - Kalenich V. (2020). Kognityvni ta komunikatyvno-pragmatychni parametry intertekstualnosti $\mathrm{v}$ mas-media [Cognitive and communicative-pragmatic parameters of intertextuality in mass media]. PSYCHOLINGUISTICS. Nr. 27(2). pp. 155-173 [in Russian]. 
Kasavin, 2007 - Kasavin I.T. (2007). Diskurs-analiz i ego primenenie v psikhologii [Discourse analysis and its application in psychology]. Voprosy psikhologii - Issues of Psycholog. Nr. 6. pp. 97-119 [in Russian].

Machikova, 2015 - Machikova M. (2015). Media v konteksti psyxolingvistyky ta media psyxologiyi [Media in the context of psycholinguistics and media psychology]. East European Journal of Psycholinguistic. Nr. 2(2). pp. 118-126. URL: http://esnuir.eenu.edu.ua/handle/123456789/9379 [in Russian].

Sklejnis, 2019 - Sklejnis V.A. (2019). Arhetipicheskie aspekty dinamiki smyslovyh struktur [Archetypal aspects of the dynamics of semantic structures]. Psiholog Psychologist. Nr. 2. pp. 1-8 [in Russian].

Block, 1963 - Block J., \& Turula E. (1963). Identification, ego control, and adjustment. Child Development. Nr. 34(4). pp. 945-953 [in English].

Brent, 2019 - Brent D.D., Kamran S., Daniel J.L. (2019). Archetype-Based Modeling and Search of Social Media. Big Data Cogn. Comput. Nr. 3(3). p. 44 [in English].

Faber, 2009 - Faber M. A., \& Mayer, J. D. (2009). Resonance to archetypes in media: There's some accounting for taste. Journal of Research in Personality. Nr. 43(3). pp. 307-322 [in English].

Faber, 2009 - Faber M. A. (2009). Understanding personality through preferences in popular mass media: An archetypal approach. Doctoral Dissertations. URL: https://scholars.unh.edu/dissertation/495 [in English].

Guo, 2018 - Guo, A., \& Ma, J. (2018). Archetype-Based Modeling of Persona for Comprehensive Personality Computing from Personal Big Data. Sensors (Basel, Switzerland). Nr. 18(3). p. 684 [in English].

Hillman, 1997 - Hillman James (1997). Archetypal Psychology: A Brief Account. Spring Publications [in English]

Jung,1968 - Jung C. G. (1968). The archetypes and the collective unconscious. 2nd ed (R. F. Hull, Trans.). Princeton, NJ: Princeton University Press [in English].

McAdams, 2008 - McAdams D. P. (2008). Personal narratives and the life story. In O. P. John, R. W. Robins, \& L. A. Pervin (Eds.). Handbook of personality: Theory and research. pp. 242-262. The Guilford Press [in English]

Pearson, 2012 - Pearson C. S. (2012). Awakening the heroes within: twelve archetypes to help us find ourselves and transform our world. New York: HarperCollins Publishers LLC. 551 p. [in English].

Rentfrow, 2006 - Rentfrow P.J., \& Gosling, S.D. (2006). Message in a Ballad: The Role of Music Preferences in Interpersonal Perception. Psychological Science. Nr. 17(3). pp. 236-242 [in English].

Schlegel, 2011 - Schlegel R.J., Hick, s J.A., King, L.A., Arndt, J. (2011). Feeling Like You Know Who You Are: Perceived True Self-Knowledge and Meaning in Life. Personality and Social Psychology Bulletin. Nr. 37 (6). pp. 745-756 [in English].

Schwartz, 2001 - Schwartz S. J. (2001). The evolution of Eriksonian and neo-Eriksonian theory and research: A review and integration. Identity. Nr. 1. pp. 7-58 [in English].

Shadraconis, 2013 - Shadraconis S. (2013) Leaders and Heroes: Modern Day Archetypes. LUX: A Journal of Transdisciplinary Writing and Research from Claremont Graduate University. Nr. 3 (1) [in English].

Shelburne, 1988 - Shelburne W.A. (1988). Mythos and logos in the thought of Carl Jung: The theory of the collective unconscious in scientific perspective. Albany, NY: SUNY Press [in English].

Received: 12 June, 2020

«Філологіч ні трактати», Том 12, № 2 ' 2020 